\title{
COMMENTARY
}

\section{AVOIDING DISAPPOINTMENT IN MARINE TOURISM}

\author{
JEFF WILKS \\ Griffith University, Parklands Drive, Southport, QLD, Australia
}

The recent High Court of Australia case of Moore $v$ Scenic Tours Pty Ltd (2020) is a timely reminder about the importance of delivering on promises in marine tourism. This is particularly relevant right now, when maintaining customer trust and confidence is considered a crucial element for industry recovery in the new normal (ABTA, 2020; Deloitte, 2020; World Travel \& Tourism Council [WTTC] \& Oliver Wyman, 2020).

The facts in Mr. Moore's case were that he and his wife booked a holiday tour, which involved a European river cruise that did not proceed as promised. According to court documents, the river cruise was promoted in Scenic's tour brochure as "a once in a lifetime cruise along the grand waterways of Europe," with guests on board the Scenic vessel treated to "all inclusive luxury." Mr. Moore and his wife chose Scenic's river cruise because they wanted to see different locations in Europe without having to unpack their belongings more than once. The river cruise also suited Mr. Moore because he found it difficult to spend extended periods of time sitting down, particularly in confined spaces, following spinal surgery. The tour was paid for 12 months in advance with what Mr. Moore described as his "life savings."

As it turned out, the cruise was severely disrupted by adverse weather conditions that resulted in high water levels on the Rhine and Main Rivers. Instead of cruising for 10 days as scheduled in the itinerary, Mr. Moore's experience was of many hours spent traveling by bus; he cruised for only 3 days. The cruise also began on board a different vessel to the luxurious Scenic Jewel, and by the time the cruise concluded in Budapest, the Moores had changed ship at least twice. In short, the holiday tour fell far short of the "once in a lifetime cruise" in "all inclusive luxury" that Mr. Moore was promised by Scenic (pages 2-3 of the judgment).

Mr. Moore's claim included "disappointment and distress for breach of a contract to provide a pleasant and relaxed holiday." He was successful, the court noting that compensation for disappointment in spoiled holiday claims was already established in other cases, notably another marine tourism case of Baltic Shipping Co v Dillon (1993).

In that case, Mrs. Dillon was a passenger on a cruise ship that struck a shoal and sank off the coast of New Zealand, on the ninth day of a 14-day voyage. Mrs. Dillon received compensation for her physical injuries, and also a figure of $\$ 5,000$ for disappointment and distress. The court held that damages for disappointment and distress are recoverable when "the contract is one the object of which is to provide enjoyment, relaxation or 
freedom from molestation" (per Chief Justice Mason, para 44).

Holiday disappointment can arise from a range of factors, including service failure by the tour operator or adverse weather events beyond the control of the operator. Both were involved in the cases described above. Disappointment in tourism, more generally, results from customer expectations not being met, even if sometimes these expectations are not realistic. Michalkó et al. (2015) pointed to tourist disappointment arising from expectations raised by the media (films, magazines, blogs), exaggerated images and promises from travel agents and tour operators, and stories of friends and relatives. Most cases of disappointment do not end up in court, but they can result in complaints, loss of repeat business, and negative word-of-mouth commentary, especially online.

One of the effects of COVID-19 has been a renewed appreciation of nature and a surge of activity to explore the outdoors, which is expected to lead to more demand for close-up and purposeful experiences with nature (WTTC \& Oliver Wyman, 2020). During lockdowns and border closures people have had many hours to dream about holidays and watch amazing documentaries of wildlife. Cater and Cater (2007) warned that marine wildlife are often, in fact, uncooperative and their interactions with humans can be disappointing. They caution that operators should not overpromise experiences.

Recent reviews suggest that the coastal and marine sector will be an early leader in global tourism recovery (Wilks, 2021), but this will require operators to guarantee customer safety and be innovative in the delivery of quality service. A good example of innovation is having skilled inwater guides in swim-with wildlife tours. Pagel (2021) reports various benefits from the presence of in-water guides, including reducing customer anxiety, elevating confidence, enhancing safety, and providing information on animal behavior. The importance of meeting customer expectations though quality marine interpretation is well established (Littlejohn et al., 2016; Lück, 2015), as is the central role of passenger briefings that clarify daily itineraries and marine safety procedures (Wilks et al., 2020), which are essential for avoiding any misunderstandings and disappointment.

Avoiding disappointment in marine tourism requires operators to be sensitive to the expectations of customers and to not overpromise experiences. Clear communication and a willingness to make appropriate and timely adjustments in response to unforeseen circumstances, such as cruise cancellations, are the lessons the tourism industry has learned from COVID-19 that will help avoid disappointment.

These messages are not new. Returning to the case of the cruise industry, in an insightful report "The Next Generation of Cruise Passengers Has Embarked" Reichheld et al. (2018) explored the five elements that contribute to a differentiated customer experience: Empower Me, Engage Me, Hear Me, Delight Me, and Know Me. They found that most cruise passengers were quite satisfied with the "basics" but had higher expectations for a personalized experience. Comparisons with restaurant and hotel groups showed cruise passengers placed additional importance on being empowered (opportunities and access to drive my experience the way I want) and delighted (create moments that surprise me and exceed my expectations). The report concluded by noting that: "It shouldn't seem surprising that cruise passengers put a premium on feeling delighted during a trip: Experience is the reason people cruise" (p. 10).

\section{References}

ABTA. (2020). Tourism for good. A roadmap for rebuilding travel and tourism. https://www.abta.com/industry-zone/ reports-and-publications/tourism-for-good

Baltic Shipping Company v Dillon 176 CLR 344. (1993). https://www.ato.gov.au/law/view/document?DocID=JU D\%2F176CLR344\%2F00002

Cater, C., \& Cater, E. (2007). Marine ecotourism: Between the devil and the deep blue sea. CABI.

Deloitte. (2020). The future of hospitality: Uncovering opportunities to recover and thrive in the new normal. https://www2.deloitte.com/content/dam/Deloitte/ca/ Documents/consumer-industrial-products/ca-future-ofhospitality-pov-aoda-en.pdf

Littlejohn, K., Needham, M. D., Szuster, B. W., \& Jordan, E. J. (2016). Pre-trip expectations and post-trip satisfaction with marine tour interpretation in Hawaii: Applying the norm activation model. The Journal of Environmental Education, 47(3), 202-212. https://doi.org/10.1080/009 58964.2016 .1162132

Lück, M. (2015). Education on marine mammal toursBut what do tourists want to learn? Ocean \& Coastal Management, 103, 25-33. https://doi.org/10.1016/j.oce coaman.2014.11.002

Michalkó, G., Irimiás, A., \& Timothy, D. J. (2015). Disappointment in tourism: Perspectives on tourism destination 
management. Tourism Management Perspectives, 16, 85-91. https://doi.org/10.1016/j.tmp.2015.07.007

Moore v Scenic Tours Pty Ltd HCA 17. (2020). http://eresources.hcourt.gov.au/showCase/2020/HCA/17

Pagel, C. D. (2021). The relevance of skilled in-water guides in swim-with wildlife tours. Tourism in Marine Environments, 16(4), 195-204. https://doi.org/10.3727/1544273 21X16273677029902

Reichheld, A., Russell, D. M., \& Teegarden, L. (2018). The next generation of cruise passengers has embarked. Deloitte. https://www2.deloitte.com/us/en/pages/consumerbusiness/articles/cruise-industry-analysis-passenger-experience-cruise-passenger-demographics. html
Wilks, J. (2021). Safety in coastal and marine tourism. In J. Wilks, D. Pendergast, P. Leggat, \& D. Morgan (Eds.), Tourist health, safety and wellbeing in the new normal. Springer.

Wilks, J., Lück, M., \& Orams, M. (2020). Passenger safety on whale watching vessels in Australia. Tourism in Marine Environments, 15(3-4), 259-270. https://doi.org/10.3727/ $154427319 X 15722432101718$

World Travel \& Tourism Council \& Oliver Wyman. (2020). To recovery \& beyond. The future of travel \& tourism in the wake of COVID-19. https://wttc.org/Portals/0/ Documents/Reports/2020/To\%20Recovery\%20and $\% 20$ Beyond-The $\% 20$ Future $\% 20$ of $\% 20$ Trave $\% 20$ Tourism $\% 20$ in $\% 20$ the $\% 20$ Wake $\% 20$ of $\% 20$ COVID- 19 . pdf?ver=2021-02-25-183120-543 
